\title{
Mechanism of Action of Tetrandrine, a Natural Inhibitor of Candida albicans Drug Efflux Pumps
}

\author{
Hong ZHANG, ${ }^{*}, a$ Aili GAO, ${ }^{a}$ Fengxia LI, ${ }^{b}$ Gehua ZHANG, ${ }^{c}$ \\ Hon In HO, ${ }^{a}$ and Wanqing $\mathrm{LIAO}^{d}$ \\ ${ }^{a}$ Department of Dermatology, The First Affiliated Hospital, Jinan University, Guangzhou 510632, \\ China, ${ }^{b}$ Department of Dermatology, The First Affiliated Hospital, Guangdong College of \\ Pharmacy, Guangzhou, China, ${ }^{c}$ The Third Affiliated Hospital, Sun Yat-sen University, \\ Guangzhou, China, and ${ }^{d}$ Department of Dermatology, Shanghai Changzheng \\ Hospital, National Laboratory of Medical Mycology, Second \\ Military Medical University, Shanghai, China
}

(Received April 1, 2008; Accepted January 31, 2009)

\begin{abstract}
Synergistic effects have previously been observed for a natural compound, tetrandrine (TET), with fluconazole (FLC) in vitro and in the treatment of Candida albicans-infected mice. To investigate the mechanisms of these synergistic effects, 16 strains of $C$. albicans from the same parent but with different FLC sensitivities were examined using flow cytometry and fluorescent spectrophotometry. Rhodamine 123 (Rh123) -positive cells and intracellular Rh123 fluorescence intensity were determined in accumulation/efflux experiments involving no or a noncytotoxic dose of TET. Total RNA extracted from each strain was used to compare the expressions of drug efflux pump genes in FLC-susceptible, -susceptible dose-dependent, and -resistant strains before and $24 \mathrm{~h}$ after TET administration. Accumulation experiments determined that mean percentages of Rh123-positive cells were 26.65\% (TET-free) and 70.99\% (TET 30 $\mu \mathrm{g} / \mathrm{ml}$ ), and mean respective intracellular Rh123 fluorescence intensities were 11.34 and 18.00. Efflux experiments showed that percentages of Rh123-positive cells were 1.79\% (TET free) and 42.57\% (TET $30 \mu \mathrm{g} / \mathrm{ml}$ ), respectively, and respective mean intracellular Rh123 fluorescence intensities were 0.74 and 2.19. Differences in $M D R 1, F L U 1, C D R 1$, and $C D R 2$ expression levels in the absence of TET were statistically significant $(p<0.05)$ between FLC-susceptible, -susceptible dosedependent, and -resistant strains. Compared with TET-free conditions, $24 \mathrm{~h}$ TET-treated strains showed statistically different $(p<0.05)$ expression of MDR1 (FLC-resistant strain), FLU1 (FLC-susceptible dose-dependent and -resistant strains), and $C D R 1$ and $C D R 2$ (FLC-susceptible, -susceptible dose-dependent, and -resistant strains). Thus TET can inhibit the $C$. albicans drug efflux system and reduce drug efflux. Its mechanism of action is related to the inhibition of expression of the drug efflux pump genes MDR1, FLU1, CDR1, and CDR2.
\end{abstract}

Key words__andida albicans; tetrandrine; drug synergism; azoles; mechanism of action

\section{INTRODUCTION}

Candida albicans is a common opportunistic fungus seen in humans, which can cause cutaneous, mucosal, subcutaneous, and systemic infections. Fluconazole (FLC) is a first-line drug in the treatment of candidiasis, ${ }^{1,2}$ but drug resistance is increasingly being observed. ${ }^{3,4)}$ Overexpression of the cell membrane drug efflux pump genes MDR1, FLU1, $C D R 1$, and $C D R 2,{ }^{3-13)}$ and alterations in the target gene $E R G 11^{14)}$ are the main mechanisms of azole drug resistance in $C$. albicans. Therefore drug efflux pump inhibitors are being sought as a method of reversing drug resistance in this organism.

In recent years, a number of studies have addressed

\footnotetext{
*e-mail: tzhangh@jnu.edu.cn
}

this issue. ${ }^{15-24)}$ Drugs such as tacrolimus ${ }^{22)}$ and cyclosporine $^{18,19)}$ can reverse $C D R$-mediated $C$. albicans FLC and ketoconazole resistance in vitro by inhibiting Cdr1p and Cdr2p, but because these drugs have significant cardio- and nephrotoxicity, their clinical applicability is low.

Tetrandrine (TET) is a low-toxicity drug extracted from the plant Stephania tetrandra S. Moore (or Fenfangji) of the Menispermaceae family. Our preliminary research demonstrated that TET can increase the sensitivity of $C$. albicans to FLC in vitro at noncytotoxic doses, ${ }^{25}$ and that the compound acts synergistically with FLC in the treatment of $C$. albicans-induced vaginitis in mice. ${ }^{26)}$ The present study utilized flow cytometry and fluorescent spectrophotometry to evaluate the effects of TET on the $C$. albicans drug efflux system, while also using the semiquantitative 
reverse-transcriptase-polymerase chain reaction (RTPCR) to examine $M D R 1, F L U 1, C D R 1$, and $C D R 2$ mRNA levels to determine the molecular mechanism of action of TET.

\section{MATERIALS AND METHODS}

Strains A series of 16 clinical isolates of C. albicans $(\mathrm{CA}-1, \mathrm{CA}-2, \ldots . ., \mathrm{CA}-17, \mathrm{CA}-10$ was not available; generously provided by Theodore $\mathrm{C}$. White, University of Washington, and the Seattle Biomedical Research Institute, USA) from a HIV-infected male who was treated with increasing doses of FLC. The MICs for this series of isolates from the patient increased at intervals, starting with an MIC of $0.25 \mu \mathrm{g} / \mathrm{ml}$ and eventually rising to an MIC greater than $64 \mu \mathrm{g} / \mathrm{ml}$. They were susceptible (CA-1, CA-2, ......, CA-12), susceptible dose-dependent (CA-13, CA-14, CA-15), and resistant (CA-16, CA-17) to FLC. Several techniques were used to demonstrate that the isolates from this series were the same strain of $C$. albicans. The resistance phenotype of the final isolate (isolate CA-16, CA-17) is genetically stable, as it persists for more than 600 generations in the absence of azoles.

Culture Media YEPD agar slant, YEPD broth, and RPMI-1640 broth (with or without 10\% bovine serum) were prepared as described in the CLSI M27A protocol. ${ }^{27)}$

Flow Cytometry Flow cytometry was utilized to determine the percentage of Rh123-positive cells in the 16 C. albicans strains before and after TET (Huico Plant Co. Ltd., Shanxi, China; purity 99.6 \%) administration and after previously detailed accumulation/efflux experiments. ${ }^{28,29)}$ During the logarithmic growth phase, recovered C. albicans was suspended in $4 \mathrm{ml}$ of sorbitol solution at a density of 5 $\times 10^{6}$ cells $/ \mathrm{ml}$. Sixty units of lyticase (Sigma, St. Louis, MO, USA) and $50 \mu$ l of $\beta$-mercaptoethanol were added, and the suspension was incubated at $37^{\circ} \mathrm{C}$ for $2 \mathrm{~h}$. Precooled $\left(4^{\circ} \mathrm{C}\right)$ phosphate-buffered saline (PBS) was used to wash the cells twice (cells and supernatant were separated by centrifugation at $744 \times g$ for $5 \mathrm{~min}$ ). Processed cells were resuspended in $3 \mathrm{ml}$ of RPMI-1640 broth and divided into three equal volumes (A, B, and C) in separate test tubes. Rh123 was added to tubes $\mathrm{A}$ and $\mathrm{B}$ at a final concentration of $2 \mu \mathrm{g} / \mathrm{ml}$. TET was additionally added to tube B at a final concentration of $30 \mu \mathrm{g} / \mathrm{ml}$. This dose has been shown to be noncytotoxic. ${ }^{25)}$ No drugs were added to tube $\mathrm{C}$. The tubes were incubated at $37^{\circ} \mathrm{C}$ for $45 \mathrm{~min}$, washed twice with precooled PBS, and $500 \mu \mathrm{l}$ was used for accumulation experiments. RPMI-1640 broth was added to the remaining suspensions in tubes $\mathrm{A}$ and $\mathrm{B}$, and TET was again added to tube $\mathrm{B}$ at the same final concentration. The tubes were incubated at $37^{\circ} \mathrm{C}$ for $45 \mathrm{~min}$, washed twice with precooled PBS, and $500 \mu \mathrm{l}$ was used for efflux experiments. Samples were examined using flow cytometry, and 10000 cells were counted in the fluorescein isothiocyanate (FITC) channel $\left(\lambda_{\text {excitation }}=488 \mathrm{~nm}, \lambda_{\text {emission }}\right.$ $=530 \mathrm{~nm})$ to construct single-parameter histograms. Data were processed with Cellques software, and the percentages of Rh123-positive cells were calculated.

Fluorescent Spectrophotometry Intracellular Rh123 fluorescence intensities before and after TET administration and after accumulation/efflux experiments ${ }^{28)}$ were determined using fluorescent spectrophtometry. Sample preparation was performed as described above. The samples were diluted with PBS to a final volume of $3 \mathrm{ml}$, and sample fluorescence intensities were measured using fluorescent spectrophotometry $\left(\lambda_{\text {excitation }}=488 \mathrm{~nm}, \lambda_{\text {emission }}=530 \mathrm{~nm}\right)$. Ultraviolet spectrophotometry was used to determine sample intracellular $\mathrm{OD}_{600}$ values, and intracellular Rh123 florescence intensities were calculated.

Extraction of Total $C$. albicans RNA Extraction was performed as previously described. ${ }^{5,6)}$ Activated $C$. albicans was inoculated in RPMI-1640 broth containing no TET or TET $30 \mu \mathrm{g} / \mathrm{ml}$, incubated at 30 ${ }^{\circ} \mathrm{C}$ for $24 \mathrm{~h}$, and the cells were collected by centrifugation. One milliliter of Trizol RNA reagent (Invitrogen, CA, USA) was added and used to disperse each cell pellet thoroughly. After complete homogenization, the sample was incubated at room temperature for $5 \mathrm{~min}$. Two hundred microliters of chloroform was added, vortexed vigorously for $15 \mathrm{~s}$, and the sample was then incubated at room temperature for 2 $\mathrm{min}$. The sample was centrifuged at $11913 \times g$ and $4^{\circ} \mathrm{C}$ for $15 \mathrm{~min}$. The supernatant was obtained, an equal volume of isopropanol was added, and the sample was incubated at room temperature for $10 \mathrm{~min}$ after mixing. The sample was centrifuged at $11913 \times g$ and $4^{\circ} \mathrm{C}$ for $10 \mathrm{~min}$. The supernatant was discarded, and ethanol $1 \mathrm{ml}$ was added prior to a $30 \mathrm{~s}$ period of vortexing. The sample was centrifuged at $4653 \times g$ and 4 ${ }^{\circ} \mathrm{C}$ for $5 \mathrm{~min}$. The supernatant was discarded, and the cells were dried before being resuspended in diethylpyrocarbonate (DEPC)-treated water and stored for 
later use. RNA sample quality was determined with $1.2 \%$ agarose gel electrophoresis as described previously. ${ }^{5)}$

cDNA Synthesis cDNA was synthesized as described previously. $\left.{ }^{6}\right)$ The reaction volume of $20 \mu \mathrm{l}$ consisted of Oligo (dt) 18 primer $1 \mu \mathrm{l}$ (Shanghai Sangon Biological Engineering Technology \& Services Co., Ltd., Shanghai, China), total RNA $2 \mu$ l, RNasin (Toyobo, Osaka, Japan) $0.5 \mu \mathrm{l}$, dNTPs $1 \mu \mathrm{l}, 10 \times$ reaction buffer $2 \mu \mathrm{l}$, and MMLV (Toyobo, Osaka, Japan) $1 \mu \mathrm{l}$, with the remaining volume composed of RNase-free water. The reaction temperatures were 37 ${ }^{\circ} \mathrm{C}$ for $90 \mathrm{~min}, 95^{\circ} \mathrm{C}$ for $10 \mathrm{~min}$, and reaction termination temperature of $4^{\circ} \mathrm{C}$. Samples were stored at -70 ${ }^{\circ} \mathrm{C}$ until use.

PCR and Product Verification Analysis Target gene and internal reference gene (18S rRNA) primer sequences and annealing temperatures are shown in Table 1 . The total reaction volume of $25 \mu \mathrm{l}$ consisted of cDNA $2 \mu \mathrm{l}$ from a single strain, target gene upstream primer $1 \mu \mathrm{l}$, target gene downstream primer 1 $\mu \mathrm{l}$, dNTPs $1 \mu \mathrm{l}$, Taq DNA polymerase $0.5 \mu \mathrm{l}$ (Shanghai Sangon Biological Engineering Technology \& Services), $10 \times$ reaction buffer $2.5 \mu \mathrm{l}$, and sterile double-distilled water $16 \mu \mathrm{l}$. The reaction conditions were $94^{\circ} \mathrm{C}$ for $3 \mathrm{~min}, 30$ cycles of $94^{\circ} \mathrm{C}$ for $40 \mathrm{~s}$, the appropriate annealing temperature (see Table 1) for 30 $\mathrm{s}$, and $72^{\circ} \mathrm{C}$ for $30 \mathrm{~s}$, followed by $72^{\circ} \mathrm{C}$ for $10 \mathrm{~min}$. Five microliters of PCR product was obtained for $2 \%$ agarose gel electrophoresis. After ethidium bromide staining, a gel electrophoresis imaging analysis system was used to perform gray value analysis for the amplified fragments. MDRI/18S rRNA, FLU1/18S rRNA,
$C D R 1 / 18 \mathrm{~S}$ rRNA, and $C D R 2 / 18 \mathrm{~S}$ rRNA ratios were used to represent the relative expression levels of $M D R 1, F L U 1, C D R 1$, and $C D R 2$, respectively.

Statistical Analyses All experiments were performed three times, and the mean values were recorded as final results. SPSS 11.5 software was used for analysis, and the results are expressed as the mean \pm S.D. In the accumulation/efflux experiments, changes in the percentage of Rh123-positive C. albicans cells were analyzed using the $\chi^{2}$ test. Changes in intracellular Rh123 fluorescence intensity and comparisons of drug efflux pump gene expression levels before and after TET administration were analyzed using the paired $t$-test. In the TET-free case, comparisons of drug efflux pump gene expression level between strains with different FLC sensitivities (susceptible, susceptible dose-dependent, and resistant) were performed using one-way analysis of variance (ANOVA). Statistical significance was defined as $p<0.05$.

\section{RESULTS}

Effects of TET on C. albicans Rh123 Accumulation and Efflux, as Determined by Flow Cytometry

For each of the $16 C$. albicans strains, 10000 cells were counted using flow cytometry in the FITC channel to construct a single-parameter histogram. The results for strains $\mathrm{CA}-3$ and $\mathrm{CA}^{-4} 4$ are shown in Fig. 1. The mean percentages of Rh123-positive cells $24 \mathrm{~h}$ after the accumulation experiments were $26.65 \%$ (TET free) and $70.99 \% \quad($ TET $30 \mu \mathrm{g} / \mathrm{ml}) \quad\left(\chi^{2}=\right.$ $62948, p=0.000)$. In the efflux experiments, the percentages were $1.79 \%$ (TET free) and $42.57 \%$ (TET $30 \mu \mathrm{g} / \mathrm{ml}$ ) (Fig. $2 ; \chi^{2}=77078, p=0.000$ ).

Table 1. Target Gene and Internal Reference Gene (18S rRNA) Primer Sequences, Annealing Temperatures, and Amplified Fragment Lengths

\begin{tabular}{|c|c|c|c|}
\hline Gene & $\begin{array}{l}\text { Primer sequence } \\
\qquad\left(5^{\prime} \rightarrow 3^{\prime}\right)\end{array}$ & $\begin{array}{l}\text { Annealing temperature } \\
\qquad\left({ }^{\circ} \mathrm{C}\right)\end{array}$ & Amplified fragment length \\
\hline 18S rRNA-F & CGAAAGCATTTACCAAGGAC & \multirow{2}{*}{58} & \multirow{2}{*}{300} \\
\hline 18S rRNA-R & TTATTGTGTCTGGACCTGG & & \\
\hline$M D R 1-\mathrm{F}$ & TGAGATTCTTGGGTGGATTC & \multirow{2}{*}{58} & \multirow{2}{*}{324} \\
\hline$M D R 1-\mathrm{R}$ & CTTGTGATTCTGTCGTTACC & & \\
\hline$F L U 1-\mathrm{F}$ & TGCTTCGGGTCCAGTTA & \multirow{2}{*}{54} & \multirow{2}{*}{300} \\
\hline$F L U 1-\mathrm{R}$ & CACAGTGAATGCTCCCA & & \\
\hline$C D R 1-\mathrm{F}$ & GCTGGTGAAGGTTTGAATGT & \multirow{2}{*}{60} & \multirow{2}{*}{213} \\
\hline$C D R 1-\mathrm{R}$ & CGCTGATGGTTGATGGATAG & & \\
\hline$C D R 2-\mathrm{F}$ & ATCTGGTGCTGGTAAGAC & \multirow{2}{*}{54} & \multirow{2}{*}{500} \\
\hline$C D R 2-\mathrm{R}$ & GCTGATGGTTGATGGATAG & & \\
\hline
\end{tabular}



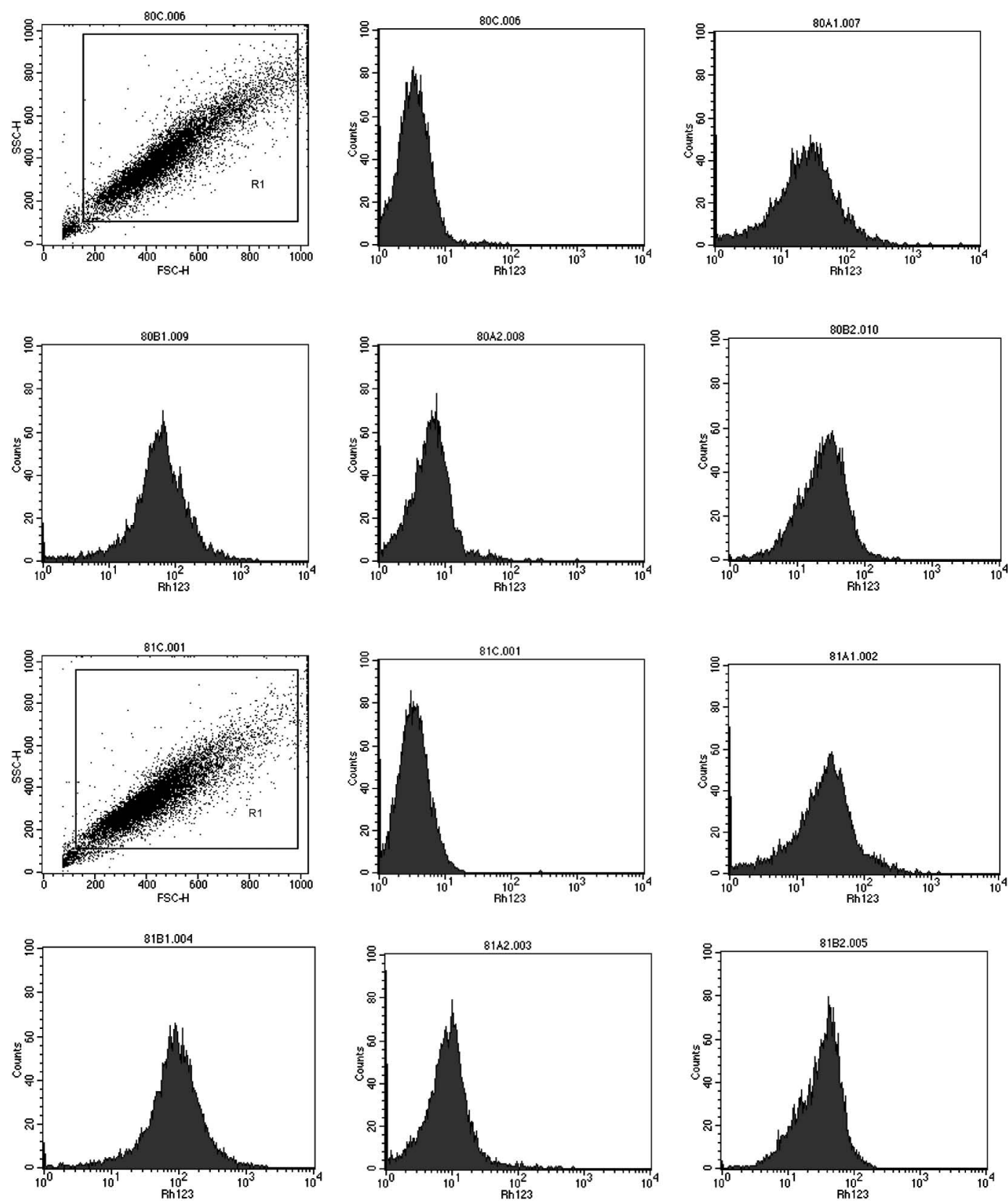

Fig. 1. Flow Cytometry Single-Parameter Histograms Showing the Effects of TET on C. albicans Rh123 Accumulation and Efflux Numbers 80 and 81 represent strains CA-3 and CA-4 respectively. C is background control, A1 is the TET free strains after the accumulation experiments, B1 is the TET $30 \mu \mathrm{g} / \mathrm{ml}$ strains after the accumulation experiments, A2 is the TET free strains after the efflux experiments, and B2 is the TET $30 \mu \mathrm{g} / \mathrm{ml}$ strains after the efflux experiments.

\section{Effects of TET on C. albicans Rh123 Accumulation} and Efflux, as Determined by Fluorescent Spectrophotometry The mean intracellular Rh123 fluorescence intensities for the 16 C. albicans strains $24 \mathrm{~h}$ after the accumulation experiments were 11.34 (TET free) and 18.00 (TET $30 \mu \mathrm{g} / \mathrm{ml}$ ), respectively. The difference was statistically significant $(t=$ $-2.506, p=0.024)$. After the efflux experiments, the intensities were 0.74 (TET free) and 2.19 (TET $30 \mu \mathrm{g}$ $/ \mathrm{ml})$, which was also a statistical difference $(t=$
$-5.428, p=0.000)$. This indicates that TET can decrease $C$. albicans Rh123 efflux and increase intracellular Rh123 accumulation (Table 2).

Analysis of MDR1, FLU1, CDR1, and CDR2 RTPCR Products before and $24 \mathrm{~h}$ after TET Administration Extracted total C. albicans RNA was examined under ultraviolet light after undergoing 1.2\% agarose gel electrophoresis. Three clear, complete electrophoresis bands corresponding to the $5.8 \mathrm{~S}, 18 \mathrm{~S}$, and $28 \mathrm{~S}$ subunits were evident. 


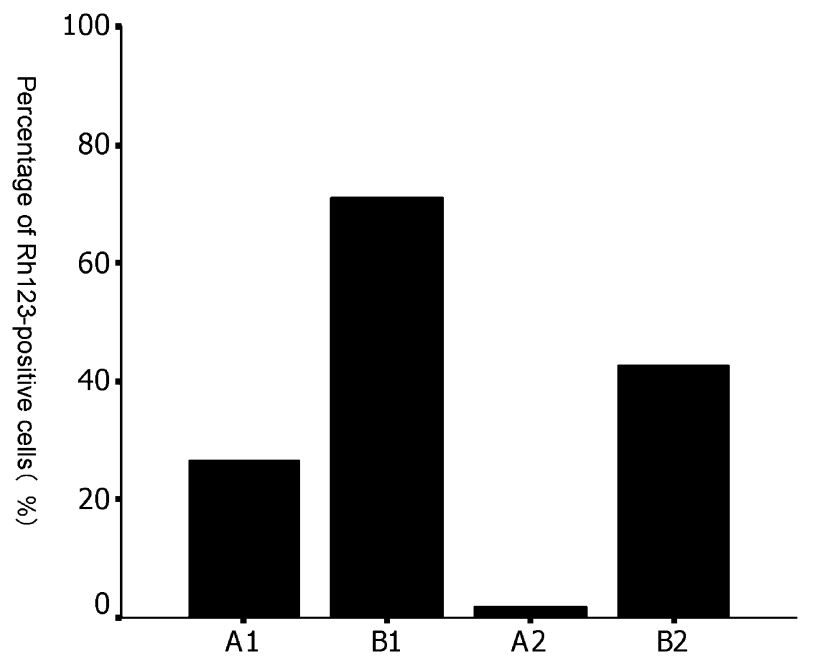

Fig. 2. Percentages of Rh123-Positive Cells in the 16 C. albicans Strains

A1 is the TET free strains after the accumulation experiments, B1 is the TET $30 \mu \mathrm{g} / \mathrm{ml}$ strains after the accumulation experiments, A2 is the TET free strains after the efflux experiments, and B2 is the TET $30 \mu \mathrm{g} / \mathrm{ml}$ strains after the efflux experiments.

Table 2. Intracellular Rh123 Fluorescence Intensities Values for the 16 C. albicans Strains

\begin{tabular}{llllll}
\hline \hline C. albicans & \multicolumn{1}{c}{$\mathrm{C}$} & \multicolumn{1}{c}{$\mathrm{A} 1$} & \multicolumn{1}{c}{$\mathrm{A} 2$} & \multicolumn{1}{c}{$\mathrm{B} 1$} & \multicolumn{1}{c}{$\mathrm{B} 2$} \\
\hline CA-1 & 0.7078 & 14.9995 & 2.1583 & 31.2118 & 2.2491 \\
CA-2 & 1.2573 & 24.4552 & 1.6208 & 22.7383 & 4.9406 \\
CA-3 & 0.4415 & 18.9154 & 0.9583 & 19.1826 & 3.7309 \\
CA-4 & 0.8406 & 20.9867 & 2.761 & 33.7805 & 5.9666 \\
CA-5 & 0.9048 & 19.6303 & 1.9093 & 33.9063 & 2.6935 \\
CA-6 & 1.0914 & 16.3929 & 3.3265 & 28.6829 & 3.7093 \\
CA-7 & 0.828 & 6.1636 & 0.9518 & 21.073 & 4.1949 \\
CA-8 & 0.7072 & 20.7643 & 2.288 & 35.2586 & 3.3996 \\
CA-9 & 0.4147 & 18.5223 & 3.1289 & 17.7162 & 4.0862 \\
CA-11 & 0.7406 & 10.0528 & 2.9896 & 19.504 & 3.0543 \\
CA-12 & 0.8039 & 13.2623 & 1.9174 & 27.7202 & 2.4253 \\
CA-13 & 0.5193 & 20.969 & 1.9916 & 24.153 & 4.7182 \\
CA-14 & 1.2572 & 16.5424 & 1.3476 & 35.9531 & 1.2534 \\
CA-15 & 0.7298 & 17.4723 & 1.8923 & 33.1425 & 5.0238 \\
CA-16 & 0.8122 & 28.3878 & 3.2281 & 28.1372 & 3.0955 \\
CA-17 & 0.8263 & 19.6547 & 1.5819 & 17.7885 & 1.9713 \\
\hline
\end{tabular}

$\mathrm{C}$ is background control, $\mathrm{A} 1$ is the TET free accumulation experimental result, A2 is the TET free efflux experimental result, B1 is the TET $30 \mu \mathrm{g} /$ $\mathrm{ml}$ accumulation experimental result, and B2 is the TET $30 \mu \mathrm{g} / \mathrm{ml}$ efflux experimental result. Background was subtracted during calculations $\left(\mathrm{OD}_{600}=0.1\right)$.

RT-PCR product semiquantitative analysis was also conducted using the internal reference gene (18S rRNA) as a standard. Target gene (MDR1, FLU1, $C D R 1$, and $C D R 2)$ mRNA levels were quantified in relation to the standard for each of the $16 C$. albicans strains. The results are shown in Table 3. In the TET free case, expression level differences for the above target genes between the FLC-susceptible, -susceptible dose-dependent, and -resistant strains were statistically significant $(p<0.05)$. In the susceptible dose-dependent and resistant strains, MDRI, FLUI, $C D R 1$, and $C D R 2$ mRNA expression levels were higher than in the susceptible strains. In the TET free and TET $30 \mu \mathrm{g} / \mathrm{ml}$ cases, expression levels of each $C$. albicans target gene were compared $24 \mathrm{~h}$ after treatment. For $M D R 1$, the difference in the FLC-resistant strain was statistically significant $(p<0.05)$. Its expression level decreased after TET administration, but the differences in the susceptible strain and the susceptible dose-dependent strain were not statistically significant $(p>0.05)$. For FLU1, the differences between the susceptible dose-dependent strain and the resistant strain were statistically significant $(p<$ $0.05)$. Its expression level decreased after TET administration, but the difference in the susceptible strain was not statistically significant $(p>0.05)$. For $C D R 1$ and $C D R 2$, the differences among the susceptible strain, susceptible dose-dependent strain, and resistant strain were all statistically significant $(p<$ 0.05 ), and their expression levels decreased after TET administration (Table 3).

\section{DISCUSSION}

We previously reported in that TET synergistically increases the candidacidal activity of TET in vitro ${ }^{25)}$ and in vivo. ${ }^{26)}$ Microdilution experiments showed that, with FLC alone, the MIC values for the 16 C. al bicans strains were $0.250-64 \mu \mathrm{g} / \mathrm{ml}$. With TET $40 \mu \mathrm{g} /$ $\mathrm{ml}$, FLC MIC values for the test organisms decreased to $0.125-16 \mu \mathrm{g} / \mathrm{ml}$. Furthermore, the endpoints were clear, and no "tailing" phenomenon was observed.25) In a mouse model of $C$. albicans vaginitis, TET and FLC in different dose combinations were administered vaginally once daily from day 3 onward for 7 days. The results showed that, up to day 11, the fungal load of the group given TET $26 \mathrm{mg} / \mathrm{kg} /$ day and FLC $26 \mathrm{mg} / \mathrm{kg} /$ day was significantly lower compared with the group given FLC $26 \mathrm{mg} / \mathrm{kg}$ /day alone. Compared with the other groups, microscopic examination of vaginal smears showed no pseudohyphae in the TET $26 \mathrm{mg} / \mathrm{kg} /$ day + FLC $26 \mathrm{mg} / \mathrm{kg} /$ day group mice, but varying amounts of pseudohyphae and pseudohyphae aggregates were seen in the other groups. Pathologic examination of vaginal tissues showed that in the TET $26 \mathrm{mg} / \mathrm{kg} / \mathrm{day}+$ FLC $26 \mathrm{mg} /$ 
Table 3. Relative C. albicans Drug Efflux Pump Gene mRNA Expression Levels of the TET Free and TET $30 \mu \mathrm{g} / \mathrm{ml} \mathrm{cases}$, at $24 \mathrm{~h}$

\begin{tabular}{|c|c|c|c|c|c|c|c|c|c|c|c|c|}
\hline \multirow{2}{*}{ C. albicans } & \multicolumn{4}{|c|}{ TET free } & \multicolumn{4}{|c|}{ TET $30 \mu \mathrm{g} / \mathrm{ml} 24 \mathrm{~h}$} & \multicolumn{4}{|c|}{$t$} \\
\hline & $M D R 1$ & $F L U 1$ & $C D R 1$ & $C D R 2$ & $M D R 1$ & FLUI & $C D R I$ & $C D R 2$ & $M D R I$ & $F L U I$ & $C D R I$ & $C D R 2$ \\
\hline FLC-susceptible & $\begin{array}{l}0.78 \pm \\
0.22\end{array}$ & $\begin{array}{r}0.73 \pm \\
0.29\end{array}$ & $\begin{array}{r}0.87 \pm \\
0.22\end{array}$ & $\begin{array}{c}0.82 \pm \\
0.21\end{array}$ & $\begin{array}{l}0.70 \pm \\
0.19\end{array}$ & $\begin{array}{c}0.63 \pm \\
0.21\end{array}$ & $\begin{array}{c}0.73 \pm \\
0.22\end{array}$ & $\begin{array}{r}0.69 \pm \\
0.24\end{array}$ & 1.922 & 1.626 & $2.658^{*}$ & $2.785^{* *}$ \\
\hline $\begin{array}{l}\text { FLC-susceptible dose- } \\
\text { dependent }\end{array}$ & $\begin{array}{r}0.96 \pm \\
0.15\end{array}$ & $\begin{array}{r}1.19 \pm \\
0.26\end{array}$ & $\begin{array}{r}1.28 \pm \\
0.19\end{array}$ & $\begin{array}{r}1.13 \pm \\
0.21\end{array}$ & $\begin{array}{r}0.83 \pm \\
0.30\end{array}$ & $\begin{array}{r}0.55 \pm \\
0.18\end{array}$ & $\begin{array}{r}0.67 \pm \\
0.25\end{array}$ & $\begin{array}{r}0.71 \pm \\
0.32\end{array}$ & 1.062 & $6.357^{* *}$ & $6.788^{* *}$ & $3.215^{*}$ \\
\hline FLC-resistant & $\begin{array}{r}1.19 \pm \\
0.42\end{array}$ & $\begin{array}{r}1.13 \pm \\
0.42\end{array}$ & $\begin{array}{r}1.25 \pm \\
0.32\end{array}$ & $\begin{array}{c}1.47 \pm \\
0.63\end{array}$ & $\begin{array}{r}0.60 \pm \\
0.40\end{array}$ & $\begin{array}{r}0.43 \pm \\
0.04\end{array}$ & $\begin{array}{r}0.59 \pm \\
0.02\end{array}$ & $\begin{array}{r}0.61 \pm \\
0.10\end{array}$ & $3.271^{*}$ & $4.190^{* *}$ & $5.134^{* *}$ & $3.246^{*}$ \\
\hline$F$ & $8.541^{* *} 1$ & $11.156^{* *}$ & $16.515^{* *}$ & $14.611^{* *}$ & & & & & & & & \\
\hline$p$ & 0.001 & 0.000 & 0.000 & 0.000 & & & & & & & & \\
\hline
\end{tabular}

Results are expressed as the mean \pm S.D. ${ }^{*} p<0.05$, ** $p<0.01$.

$\mathrm{kg} /$ day group, mucosal edema was slight with minimal inflammatory cell infiltration, and no pseudohyphae were found within vaginal cavities and mucosal layers. ${ }^{26)}$

The main molecular mechanisms of azole drug resistance in C. albicans are most often overexpression of efflux pumps ${ }^{3,6,7)}$ and mutation-mediated overexpression of genes that code for proteins targeted by azole drugs. ${ }^{14)}$ Two types of efflux pump system are active in the drug-resistance process. The first involves ATP-binding cassette transporters (ABC, coded by $C D R$ genes), which are ATP-dependent active transporters. ${ }^{10,11)}$ In $C$. albicans, efflux pumps in the $\mathrm{ABC}$ superfamily include Cdr1p and Cdr2p, coded by $C D R 1$ and $C D R 2$, respectively. ${ }^{8,9,11)}$ Efflux pumps belonging to this superfamily are ubiquitously present and structurally similar in organisms ranging from prokaryotic cells to mammals. ${ }^{30)}$ In mammalian cells, they are present mainly in the form of the transmembrane protein P-gp (coded by MDRI), ${ }^{31,32)}$ and in fungi they are mainly multidrug-resistance proteins (MRPs, mainly Cdrp) . ${ }^{11)}$ In addition to their major function of extruding harmful material from the cell, upregulation of their activity is intimately related to antiparasitic resistance in parasites and chemotherapy resistance in tumors. ${ }^{30)}$ The second type of efflux pump is the major facilitator superfamily (MFS, coded by $M D R$ genes), which are electrochemical gradient-dependent passive transporters. In $C$. albicans, they include CaMdr1p and Flu1p, coded by CaMDR $1^{16)}$ and $F L U 1{ }^{5)}$ respectively. A molecular epidemiologic study of $C$. albicans FLC resistance showed that $83 \%$ of drug resistance is related to $C D R 1$ overexpression, and $67 \%$ is related to CaMDR1 overexpression. ${ }^{3)}$

$\mathrm{Rh} 123$ is a cationic dye with a high fluorescence quantum yield and no cytotoxicity. It is generally believed that Rh123 enters cells by diffusion before being pumped out of cells by efflux pumps of the ABC superfamily. ${ }^{28)}$ It is the substrate of many $M D R$ efflux pumps including Cdr1p and Cdr2p and can be used to evaluate efflux function in tumor cells such as those possessing P-gp. ${ }^{28,29)}$ We compared the percentages of Rh123-postive cells and intracellular Rh123 fluorescence intensities in C. albicans strains before and after TET administration to evaluate the effects of TET on drug efflux pump function (such as Cdr1p and Cdr2p). Our results from accumulation/efflux experiments demonstrated that the mean percentages of Rh123-positive cells and mean intracellular Rh123 fluorescence intensities in the 16 C. albicans strains exposed to noncytotoxic doses of TET were significantly higher than in the unexposed strains. These observations indicate that TET can inhibit the drug efflux pump function in C. albicans, decreasing drug efflux activity and hence increasing intracellular Rh123 accumulation.

The RT-PCR results showed that prior to TET administration mRNA expression levels of the drug efflux pump genes $M D R 1, F L U 1, C D R 1$, and $C D R 2$ in the susceptible dose-dependent strain and the resistant strain were significantly higher than in the susceptible strain. Twenty-four hours after the administration of noncytotoxic doses of TET, the expression levels of MDRI (resistant strain), FLUI (susceptible dose-dependent strain and resistant strain), CDRI (susceptible strain, susceptible dosedependent strain, and resistant strain), and CDR2 (susceptible strain, susceptible dose-dependent strain, and resistant strain) all significantly decreased compared with those before TET administration. This indicates that, in terms of mRNA levels, the 
mechanism of the synergistic effect of TET on the candidacidal activity of FLC is related to the inhibition of the genes coding for the drug efflux pumps. It was also found that, among different strains (even strains with the same MIC), MDR1, FLU1, CDR1, and $C D R 2$ expression levels were not completely identical. After TET administration, the mean expression levels of each target gene mRNA were also downregulated to different degrees, suggesting the possible existence of other mechanisms in addition to the four efflux pumps described above, or a situation in which the mRNA expression level is not directly indicative of efflux pump function. It can be seen from the present results that the mechanism of TET in reversing $C$. albicans FLC resistance is similar to its mechanism in reversing chemotherapy resistance in human tumor cells.

RT-PCR has the advantages of simplicity, high sensitivity, and high efficacy, making it suitable for detecting multiple genes in large samples. Our study performed three parallel experiments under identical conditions and implemented corrections using the housekeeping gene (18S rRNA) as the internal reference gene, thereby increasing quantification accuracy.

TET is a bis-benzylisoquinoline alkaloid, which is the main active component in the root of $S$. tetrandra S. Moore (or Fenfangji) of the Menispermaceae family. ${ }^{33)}$ TET has been used in the treatment of hypertension, cardiac arrhythmia, and angina pectoris in China since the $1950 \mathrm{~s}^{33,34)}$ and few side effects have been noted in clinical practice. TET has been shown to be a $\mathrm{Ca}^{2+}$ channel antagonist and to interact with the voltage-activated L-type and T-type $\mathrm{Ca}^{2+}$ channels and the slowly gating $\mathrm{K}_{(\mathrm{Ca})}$ channel with varying degrees of specificity and affinity. ${ }^{33)}$ Recent studies have shown that TET has a reversal effect on P-gp-mediated MDR. ${ }^{32,35)}$ In preliminary screening, TET was shown to be more potent than other herbs in modulating $M D R$ in vitro. ${ }^{34)}$ The $C$. albicans drug efflux pumps Cdr1p and Cdr2p are highly homologous to $\mathrm{P}$-gp and have similar structures and functions. ${ }^{30)} \mathrm{Cdr} 1 \mathrm{p}$ and $\mathrm{Cdr} 2 \mathrm{p}$ are also intimately related to $C$. albicans FLC drug resistance.9,11) The present study showed that TET can increase the candidacidal activity of FLC by decreasing Cdr1p and Cdr2p FLC efflux.

In summary, tetrandrine, a Chinese herb extract, has no intrinsic antifungal activity against $C$. albicans at concentrations of less than $40 \mu \mathrm{g} / \mathrm{ml}$ but is a potent synergist in combination with FLC in vitro and in vivo. The main mechanism of action of TET may be to reverse $C D R 1, C D R 2, M D R 1$, and FLU1 associated with an increase in the intracellular azole accumulation by inhibiting the overexpression of MRP, CaMdr1p, and Flu1p and may interact directly with multidrug efflux transporters present in $C$. albicans. Thus, by inhibiting their activity, this drug could increase the susceptibility of $C$. albicans to azoles. Clearly, the effects of TET in combination with azoles needs to be more thoroughly investigated. This new concept of combining FLC, and perhaps other azoles, with TET or with its analogue compounds might open a new therapeutic approach for the management of fungal infections.

Acknowledgments This work was supported by the Foundation of Science and Technology Research Program of Gongdong, PR China ( No. 2004B33101004, 2008B030301350). We thank Professor Theodore C. White, University of Washington, and the Seattle Biomedical Research Institute, USA, for generously providing C. albicans isolates.

\section{REFERENCES}

1) Arikan S., Med. Mycol., 45, 569-587 (2007).

2) Chen S. C., Sorrell T. C., Med. J. Aust., 187, 404-409 (2007).

3) Perea S., Lopez-Ribot J. L., Kirkpatrik W. R., McAtee R. K., Santillan R. A., Martinez M., Calabrese D., Sanglard D., Patterson T. F., Antimicrob. Agents Chemother., 45, 2676-2684 (2001).

4) White T. C., Pfaller M. A., Rinaldi M. G., Smith J., Redding S. W., Oral Dis., 3, S102S109 (1997).

5) Calabrese D., Bille J., Sanglard D., Microbiology, 146, 2743-2754 (2000).

6) Hiller D., Sanglard D., Morschhauser J., Antimicrob. Agents Chemother., 50, 1365-1371 (2006)

7) Karababa M., Coste A. T., Rogon B., Bille J., Sanglard D., Antimicrob. Agents Chemother., 48, 3064-3079 (2004).

8) Nakamura K., Niimi M., Niimi K., Holmis A. R., Yates J. E., Dceottingnies A., Monk B. C., Goffeau A., Cannon R. D., Antimicrob. Agents Chemother., 45, 3366-3374 (2001).

9) Sanglard D., Ischer F., Monod M., Bille J., 
Microbiology, 143, 405-416 (1997).

10) Schuetzer-Muchlbauer M., Willinger B., Egner R., Ecker G., Kuchler K., Int. J. Antimicrob. Agents, 22, 291-300 (2003).

11) Wada S., Niimi M., Niimi K., Holmes A. R., Monk B. C., Cannon R. D., Uehara Y., J. Biol. Chem., 277, 46809-46821 (2002).

12) White T. C., Holleman S., Dy F., Mirels L. F., Stevens D. A., Antimicrob. Agents Chemother., 46, 1704-1713 (2002).

13) Wirsching S., Michel S., Köhler G., Morschhäuser J., J. Bacteriol., 182, 400-404 (2000) .

14) Prasad R., Kapoor K., Int. Rev. Cytol., 242, 215-248 (2005).

15) Han Y., Phytomedicine, 14, 733-738 (2007).

16) Han Y., Lee J. H., Biol. Pharm. Bull., 28, 541544 (2005).

17) Li Y., Sun S., Guo Q., Ma L., Shi C., Su L., Li H., J. Antimicrob. Chemother., 61, 577585 (2008).

18) Marchetti O., Entenza J. M., Sanglard D., Bille J., Glauser M. P., Moreillon P., Antimicrob. Agents Chemother., 44, 2932-2938 (2000).

19) Marchetti O., Moreillon P., Glauser M. P., Bille J., Sanglard D., Antimicrob. Agents Chemother., 44, 2373-2381 (2000).

20) Ogita A., Fujita K., Taniguchi M., Tanaka T., Planta Med., 72, 1247-1250 (2006).

21) Shin S., Kang C. A., Lett. Appl. Microbiol., 36, 111-115 (2003).

22) Sun S., Li Y., Guo Q., Shi C., Yu J., Ma L., Antimicrob. Agents Chemother., 52, 409-417 (2008).

23) Tanabe K., Lamping E., Adachi K., Takano Y., Kawabata K., Shizuri Y., Niimi M., Ue- hara Y., Biochem. Biophys. Res. Commun., 364, 990-995 (2007).

24) Tanida T., Okamoto T., Ueta E., Yamamoto T., Osaki T., J. Antimicrob. Chemother., 57, 94-103 (2006).

25) Li F., Zhang H., Chin. J. Dermatol., 39, 454456 (2006).

26) Wang K.-L., Zhang H., Jiang H.-H., Shi J.P., Gao A.-L., Ho H.-I., Chao H.-A., Chin. J. Zoonoses, 23, 474-478 (2007).

27) National Committee for Clinical and Laboratory Standards. 1997. Reference method for broth dilution antifungal susceptibility testing of yeasts, vol. 17, no. 9. Approved standard. Document M27-A. National Committee for Clinical and Laboratory Standards, Wayne, $\mathrm{Pa}$.

28) Clark F. S., Parkinson T., Hitchcock C. A., Gow N. A., Antimicrob. Agents Chemother., 40, 419-425 (1996).

29) Maesaki S., Marichal P., Vanden Bossche H., Sanglard D., Kohno S., J. Antimicrob. Chemother., 44, 27-31 (1999).

30) Van Veen H. W., Konings W. N., Semin. Cancer Biol., 8, 183-191 (1997).

31) Fu L., Liang Y., Deng L., Ding Y., Chen L., Ye Y., Yang X., Pan Q., Cancer Chemother. Pharmacol., 53, 349-356 (2004).

32) Wang F. P., Wang L., Yang J. S., Nomura M., Miyamoto K., Biol. Pharm. Bull., 28, 1979-1982 (2005).

33) Wang G., Lemos J. R., Life Sci., 56, 295-306 (1995).

34) Tian H., Pan Q. C., Yao Xuе Xue Bao, 32, 245-250 (1997).

35) Jin J., Wang F. P., Wei H., Liu G., Cancer Chemother. Pharmacol., 55, 179-188 (2005). 